\title{
ANALISIS YURIDIS BUKTI DIGITAL (DIGITAL EVIDENCE) DALAM PEMBUKTIAN PERKARA TINDAK PIDANA UJARAN KEBENCIAN PADA PUTUSAN PENGADILAN NEGERI MEDAN NO. 3168/PID.SUS/2018/PN.MDN \\ JURIDICAL ANALYSIS OF DIGITAL EVIDENCE IN PROVING CASES OF CRIME OF HATE SPEECH IN MEDAN DISTRICT COURT DECISIONS NO. 3168/PID.SUS/2018/PN.MDN.
}

I Made Dwi Krisnanda, Madiasa Ablisar, Sunarmi, Mahmud Mulyadi

Program Studi Magister Ilmu Hukum Fakultas Hukum Universitas Sumatera Utara, Medan madedwi222@gmail.com

Naskah dikirim : 7 Oktober 2020

Naskah diterima untuk diterbitkan : 27 Juli 2021

DOI : $10.34010 /$ rnlj.v\%vi\%i.3862

\begin{abstract}
Law No. 8 of 1981 concerning the Criminal Procedure Code (hereinafter referred to as the Criminal Procedure Code), has set the evidence that can be done in front of the trial. Article 183 of the Criminal Procedure Code implies that a minimum of 2 (two) valid evidence are required. Article 184 paragraph (1) of the Criminal Procedure Code regulates valid evidence, namely: witness statements; expert statements; letter; instructions; and the statement of the defendant. However, since the trial of Jesica Kumala Wongso which was broadcast on television almost every day, it turns out there is one more proof that is not contained in the Criminal Procedure Code, namely: digital evidence. The object of this study is the Medan District Court Decision No. 3168/Pid.Sus/2018/PN.Mdn., Dated May 23, 2019, concerning the use of digital evidence An. Defendant HDL Alias Himma for alleged "criminal acts of hate speech". Law No. 11 of 2008 as amended by Law No. 19 of 2016 concerning Amendments to the Information and Electronic Transaction Law which governs electronic evidence. The problems in this study, namely: the position of proof of digital evidence before the trial is associated with criminal conviction; use of digital evidence in criminal acts of hate speech on social media; and juridical analysis of digital evidence in proving criminal acts of hate speech in Medan District Court Decision No. 3168/Pid.Sus/ 2018/PN.Mdn.
\end{abstract}

Keywords. Digital evidence; proof of criminal offenses; hate speech.

\section{ABSTRAK}

Undang-Undang No. 8 Tahun 1981 tentang Kitab Undang-Undang Hukum Acara Pidana (selanjutnya disebut Kitab Undang-Undang Hukum Acara Pidana), telah mengatur bukti-bukti yang bisa dilakukan di depan persidangan. Pasal 183 KUHAP menyiratkan bahwa diperlukan minimal 2 (dua) alat bukti yang sah. Pasal 184 ayat (1) KUHAP mengatur tentang alat bukti yang sah, yaitu: keterangan saksi; pernyataan ahli; surat; instruksi; dan pernyataan terdakwa. Namun sejak persidangan Jesica Kumala Wongso yang hampir setiap hari tayang di televisi, ternyata ada satu lagi bukti yang tidak terdapat dalam KUHAP yaitu: bukti digital. Objek penelitian ini adalah Putusan Pengadilan Negeri Medan No. 3168/Pid.Sus/2018/PN.Mdn., tanggal 23 Mei 2019, tentang Penggunaan Alat Bukti Digital An. Terdakwa HDL Alias Himma atas tuduhan "tindak pidana ujaran kebencian". Undang-Undang No. 11 Tahun 2008 sebagaimana telah diubah dengan Undang-Undang No. 19 Tahun 2016 tentang Perubahan Atas Undang-Undang Informasi dan Transaksi Elektronik yang mengatur tentang alat bukti elektronik. Permasalahan dalam penelitian ini, yaitu: posisi alat bukti digital sebelum persidangan dikaitkan dengan pemidanaan; penggunaan bukti digital dalam tindak pidana ujaran kebencian di media sosial; dan analisis yuridis bukti digital dalam pembuktian tindak pidana ujaran kebencian dalam Putusan Pengadilan Negeri Medan No. 3168/Pid.Sus/2018/PN.Mdn.

Kata Kunci. Bukti digital; pembuktian tindak pidana; ujaran kebencian. 


\section{PENDAHULUAN}

Penelitian ini membahas mengenai pembuktian dalam hukum acara pidana, dan oleh karenanya pembuktian dalam hukum acara perdata tidak akan dibahas lebih lanjut. Berdasarkan Undang-Undang No. 8 Tahun 1981 tentang Hukum Acara Pidana (selanjutnya disebut KUHAP), telah mengatur bagaimana cara pembuktian yang dapat dilakukan di depan persidangan dan bagaimana hakim bersikap di dalam putusannya terhadap suatu perkara. Pasal 183 KUHAP, bahwa: "Hakim tidak boleh menjatuhkan pidana kepada seseorang kecuali apabila dengan sekurangkurangnya dua alat bukti yang sah ia memperoleh keyakinan bahwa suatu tindak pidana benar-benar terjadi dan bahwa terdakwalah yang bersalah melakukannya". Penjelasan Pasal 183 KUHAP, menyebutkan: "Ketentuan ini adalah untuk menjamin tegaknya kebenaran, keadilan dan kepastian hukum bagi seseorang". Sehingga untuk memahami ketentuan Pasal 183 KUHAP tersebut mengadopsi dari ketentuan Pasal 294 Herzien Inlandsch Reglement (H.I.R), yang dianggap sebagai pembuktian menurut undang-undang secara negatif. ${ }^{1}$

Dari ketentuan Pasal 183 KUHAP tersebut tersirat bahwa dibutuhkan minimal 2 (dua) alat bukti yang dapat menjadi pegangan hakim sebelum menjatuhkan putusan, sehingga kemudian perlu dipahami pula ketentuan Pasal 184 ayat (1) KUHAP mengenai alat bukti yang sah, yaitu: "Keterangan saksi; Keterangan ahli; Surat; Petunjuk; dan Keterangan Terdakwa". 2

Penelitian ini membatasi pembahasan pada alat bukti berupa "surat" maupun "petunjuk" sesuai Pasal 184 ayat (1) huruf c dan huruf d KUHAP. Mengenai "surat", telah diatur dalam Pasal 187 KUHAP, menyatakan bahwa:

"Surat sebagaimana dimaksud pada Pasal 184 ayat (1) huruf c, dibuat atas sumpah jabatan atau dikuatkan dengan sumpah adalah :

a. Berita Acara dan surat lain dalam bentuk resmi yang dibuat oleh pejabat umum yang berwenang atau yang dibuat di hadapannya, yang memuat keterangan tentang kejadian atau keadaan yang didengar, dilihat atau dialaminya sendiri, disertai dengan alasan yang jelas dan tegas tentang keterangannya itu;

b. Surat yang dibuat menurut ketentuan peraturan perundang-undangan atau surat yang dibuat oleh pejabat mengenai hal yang termasuk dalam tata laksana yang menjadi tanggung jawab dan yang diperuntukkan bagi pembuktian sesuatu hal atas sesuatu keadaan;

c. Surat keterangan dari seorang ahli yang memuat pendapat berdasarkan keahliannya mengenai sesuatu hal atau sesuatu keadaan yang diminta secara resmi dari padanya;

d. Surat lain dapat berlaku jika ada hubungan dengan isi dari alat pembuktian yang lain".

Dalam Penjelasan Pasal 187 KUHAP, pada huruf b saja yang mendapatkan penjelasan, sebagai berikut: "Yang dimaksud dengan surat yang dibuat oleh pejabat termasuk surat yang dikeluarkan oleh suatu majelis yang berwenang untuk itu".

${ }^{1}$ Ibid., hal. 280. Lihat juga: Pasal 294 Herzien Inlandsch Reglement (H.I.R) atau Reglemen Indonesia Yang Diperbaharui (Staatsblad 1984 : No. 16 yang diperbaharui dengan Staatsblad 1941 No. 44) berlaku untuk Jawa dan Madura, menyatakan bahwa: “(1) Tidak akan dijatuhkan hukuman kepada seorangpun jika hakim tidak mendapat keyakinan dengan upaya bukti menurut undang-undang bahwa benar telah terjadi perbuatan pidana dan bahwa pesakitan salah melakukan perbuatan itu; (2) Atas persangkaan saja atau bukti-bukti yang tidak cukup, tidak seorangpun yang dapat dihukum.

Penjelasan: Untuk memutuskan perkara telah diadakan peraturan-peraturan tentang pembuktian dalam bagian ini peraturan-peraturan, yang meliputi: macamnya alat-alat bukti yang manakah yang boleh dipakai oleh hakim. Cara memakai alat-alat bukti, ialah ketentuan-ketentuan banyaknya alat-alat bukti yang harus ada untuk menetapkan kesalahan terdakwa”.

${ }^{2}$ Undang-Undang No. 8 Tahun 1981 tentang Hukum Acara Pidana yang dikenal dengan Kitab Undang-Undang Hukum Acara Pidana (KUHAP). 
Vol. 3 No. 2 Juli 2021

Mengenai kekuatan pembuktian surat, M. Yahya Harahap, membagi ke dalam dua segi, yaitu: segi formil dan segi materiil. Dari segi formil, bukti surat mempunyai nilai pembuktian formal yang sempurna, dengan sendirinya bentuk dan isi surat tersebut: ${ }^{3}$

a. "Sudah benar, kecuali dapat dilumpuhkan dengan alat bukti yang lain;

b. Semua pihak tidak dapat lagi menilai kesempurnaan bentuk dan pembuatannya;

c. Juga tidak dapat menilai kebenaran keterangan yang dituangkan pejawab berwenang di dalamnya sepanjang isi keterangan tersebut tidak dapat dilumpuhkan dengan alat bukti lain;

d. Isi keterangan yang tertuang di dalamnya dapat dilumpuhkan dengan alat bukti yang lain, baik berupa alat bukti keterangan saksi, keterangan ahli atau keterangan Terdakwa".

Dari segi materiil, nilai kekuatan pembuktian alat bukti surat sama halnya dengan nilai pembuktian keterangan saksi dan alat bukti keterangan ahli, yaitu sama-sama mempunyai kekuatan pembuktian yang bersifat bebas, sehingga hakim bebas untuk menilai kekuatan pembuktian dengan alasan: ${ }^{4}$

a. "Asas proses pemeriksaan perkara pidana ialah untuk mencari kebenaran materiil atau kebenaran sejati (materiil waarheid) bukan kebenaran formal, sehingga hakim bebas menilai kebenaran yang terkandung pada alat bukti surat;

b. Asas keyakinan hakim, yaitu hakim dapat menjatuhkan pemidanaan kepada Terdakwa apabila telah diperoleh minimal 2 (dua) alat bukti yang sah;

c. Asas batas minimum pembuktian, dalam arti meskipun melekat sifat kesempurnaan secara formal atas bukti surat, akan tetapi alat bukti surat tidak cukup sebagai alat bukti yang berdiri sendiri dan tetap memerlukan dukungan dari alat bukti lainnya".

Mengenai alat bukti petunjuk adalah sebagaimana tercantum dalam Pasal 188 KUHAP, yang menyebutkan:

(1) "Petunjuk adalah perbuatan, kejadian atau keadaan, yang karena persesuaiannya, baik antara yang satu dengan yang lain, maupun dengan tindak pidana itu sendiri, menandakan bahwa telah terjadi suatu tindak pidana dan siapa pelakunya.

(2) Petunjuk sebagaimana dimaksud dalam ayat (1) dapat diperoleh dari:

a. Keterangan saksi;

b. Surat;

c. Keterangan Terdakwa.

(3) Penilaian atas kekuatan pembuktian dari suatu petunjuk dalam setiap keadaan tertentu dilakukan oleh hakim dengan arif lagi bijaksana, setelah ia mengadakan pemeriksaan dengan penuh kecermatan dan keseksamaan berdasarkan hati nuraninya".

Penjelasan Pasal 188 KUHAP menyebutkan "cukup jelas", sehingga dalam praktek diperlukan kehati-hatian yang sangat mendalam dan kecermatan dari setiap hakim terhadap alat bukti berupa petunjuk. Terhadap nilai kekuatan pembuktian alat bukti petunjuk, juga bersifat bebas dalam $\operatorname{arti}^{5}$

a. "Hakim tidak terikat atas kebenaran persesuaian yang diwujudkan oleh petunjuk;

b. Petunjuk sebagai alat bukti, tidak bisa berdiri sendiri membuktikan kesalahan Terdakwa dan tetap terikat kepada prinsip batas minimum pembuktian".

Sebelum membahas mengenai alat bukti ilmiah, maka perlu mengetahui pengertian bukti empiris adalah informasi yang membenarkan suatu kepercayaan dalam kebenaran atau kebohongan suatu klaim empiris dan dalam pandangan empiris, seseorang dapat mengklaim memiliki pengetahuan saat seseorang memiliki sebuah kepercayaan yang benar berdasarkan bukti empiris.

\footnotetext{
${ }^{3}$ M. Yahya Harahap, Op.cit., hlm. 310-312.

${ }^{4}$ Ibid.

${ }^{5}$ Ibid., hlm. 317.
} 
Vol. 3 No. 2 Juli 2021

Dalam bukti empiris, indra adalah sumber utama dari bukti empiris. Walaupun sumber lain dari bukti, seperti ingatan, dan kesaksian dari yang lain pasti ditelusuri kembali lagi ke beberapa pengalaman indrawi, semuanya dianggap sebagai tambahan, atau tidak langsung. Bukti empiris ini yang dalam istilah hukum diaplikasikan dalam keterangan saksi, yaitu orang yang melihat, mendengar dan mengetahui secara langsung atas suatu tindak pidana yang dilakukan oleh seorang terdakwa (dalam perkara pidana) atau terhadap suatu peristiwa hukum yang menjadi sebab akibat atas peristiwa hukum yang lain (dalam perkara perdata). ${ }^{6}$

Kesulitan yang dihadapi ketika mengandalkan alat bukti saksi adalah berkenaan dengan keterbatasan seorang saksi dalam mengingat kembali kejadian yang pernah saksi lihat, saksi ketahui maupun saksi dengar, yang kejadian tersebut sudah berlangsung dalam jangka waktu yang lama. Sangat manusiawi apabila seorang saksi harus mengingat kembali kejadian yang sudah lama terjadi. Oleh sebab itu, kemudian dibutuhkan bantuan dalam bentuk surat, yang tidak lain juga berisi atau mencatat kejadian-kejadian penting pada suatu waktu. Surat apapun dapat diajukan di persidangan akan tetapi yang dapat dijadikan alat bukti yang dipertimbangkan dalam persidangan adalah alat bukti surat yang bersifat otentik atau surat yang dibuat dan disahkan oleh pejabat yang berwenang, misalkan Akta Jual Beli yang dibuat dan disahkan di Kantor Notaris. ${ }^{7}$

Dalam perkembangannya, tidak cukup dengan menggunakan alat bukti surat, sehingga perlu adanya ahli yang dapat memberikan penjelasan secara ilmiah terhadap suatu peristiwa hukum yang terjadi. Keberadaan ahli ini berkembang menjadi digunakannya alat bukti ilmiah (digital evidence) dalam proses pembuktian di persidangan.

Terhadap keterangan ahli ini, Kejaksaan Agung RI pernah melakukan kajian tentang "Peranan Alat Bukti Keterangan Ahli Dalam Penanganan Perkara Tindak Pidana Korupsi". Adapun hasil kajian Kejaksaan Agung RI tersebut, adalah sebagai berikut: ${ }^{8}$

1. "Peran pembuktian sangat penting dalam suatu proses hukum di pengadilan, bila salah dalam menilai pembuktian akan mengakibatkan putusan yang salah pula. Untuk menghindari atau setidak-tidaknya meminimalkan putusan-putusan pengadilan yang demikian, kecermatan dalam menilai alat bukti di pengadilan sangat diharapkan, terutama dalam kasus tindak pidana korupsi.

2. Peranan ahli dalam pemeriksaan tingkat penyidikan kasus Tindak Pidana Korupsi maupun pemeriksaan dalam sidang pengadilan semakin diperlukan. Pemeriksaan ahli akan menjadi mutlak manakala jaksa memberikan petunjuk kepada penyidik untuk dilakukan pemeriksaan ahli.

3. Dalam hal hakim membentuk keyakinan tentang kesalahan terdakwa melakukan tindak pidana korupsi, secara formal kedudukan alat bukti keterangan ahli adalah sama dengan alat bukti lain. Artinya, keyakinan boleh dibentuk atas dasar keterangan ahli dan alat bukti petunjuk saja, karena telah memenuhi minimum bukti dimaksud Pasal 183 KUHAP. Hukum penyimpangan pembuktian yang ada dalam hukum pidana korupsi, terdapat pada 2 (dua) hal pokok, yaitu: mengenai bahan-bahan yang dapat digunakan untuk membentuk alat bukti petunjuk dan mengenai sistem pembebanan pembuktian".

Pada perkara-perkara yang mengharuskan pembuktian yang berkaitan dengan data elektronik, maka dikenal dengan adanya istilah Digital Forensic, yaitu sebagai satu bidang spesialisasi ilmu pengetahuan dan teknologi komputer yang memiliki posisi signifikan untuk melakukan investigasi kasus-kasus computer crime dan/atau computer related crime. Dengan

${ }^{6}$ Santhos Wachjoe Prijambodo, “Alat Bukti Ilmiah”, Makalah Mahasiswa Program Doktoral pada Program Doktoral Ilmu Hukum (PDIH) Fakultas Hukum Universitas Islam Sultan Agung, Semarang, 12 April 2016.

${ }^{7}$ Ibid.

${ }^{8}$ Pusat Litbang Kejaksaan Agung RI, "Studi Tentang Peranan Alat Bukti Keterangan Ahli Dalam Penanganan Perkara Tindak Pidana Korupsi”, Litbang Kejagung RI, Jakarta, 2008. 
Vol. 3 No. 2 Juli 2021

menggunakan Digital Forensic, maka segala jenis data elektronik dapat digunakan sebagai alat bukti di persidangan, sebab Digital Forensic mengolah data-data elektronik menjadi data yang dapat dibaca dan dimengerti oleh setiap orang khususnya bagi para penegak hukum, hal ini disebabkan data elektronik bukan berupa data yang berisi tulisan huruf atau angka tetapi kadangkala juga merupakan bahasa komputer yang dapat dimengerti dan dipahami oleh orang-orang yang berkecimpung di dunia keilmuan digital. ${ }^{9}$

Hal lain yang harus diperhatikan dalam penggunaan alat bukti ilmiah adalah keterlibatan pihak laboratorium forensik, baik dalam mengolah data-data berupa data elektronik maupun datadata yang berkaitan dengan pengungkapan DNA seseorang. Saat ini, terdapat sedikit orang yang memiliki keinginan untuk mendalami keilmuan di bidang laboratorium forensik, meskipun sebenarnya hasil dari laboratorium forensik menjadi penentu dari adanya alat bukti ilmiah. ${ }^{10}$

Penggunaan alat bukti ilmiah tentu akan membawa suatu dampak pada hukum acara pembuktian dan akan menggeser paradigma pembuktian di persidangan sebagaimana diatur dalam Pasal 184 ayat (1) KUHAP tentang alat bukti di dalam hukum pidana. Tidak menutup kemungkinan bahwa suatu saat nanti ketika terdapat pembaharuan terhadap hukum acara di Indonesia dalam bentuk pembaharuan Kitab Hukum Acara, alat bukti ilmiah menjadi alat bukti utama dalam pembuktian di persidangan namun tentunya juga tidak mengesampingkan alat bukti lainnya. ${ }^{11}$

Berdasarkan ketentuan Pasal 183 KUHAP tersebut, telah secara limitatif menentukan bahwa bukti yang dibutuhkan untuk menghukum seorang Terdakwa dikenal dengan 5 (lima) jenis, yaitu: keterangan saksi, keterangan ahli, surat, petunjuk, dan keterangan Terdakwa. Namun, sejak persidangan Jesica Kumala Wongso yang disiarkan di televisi hampir setiap hari, ternyata ada satu bukti lagi yang tidak terdapat di dalam KUHAP, yaitu bukti ilmiah (digital evidence). ${ }^{12}$ Dalam penggunaan alat bukti ilmiah dibutuhkan keterlibatan pihak laboratorium forensik, baik dalam mengolah data-data berupa data elektronik maupun data-data yang berkaitan dengan pengungkapan DNA seseorang.

Mengenai pengungkapan DNA seseorang ini menurut Yurisprudensi Mahkamah Agung RI melalui Putusan Mahkamah Agung RI No. 664K/Pid.Sus/2014, tertanggal 29 Oktober 2014, menyatakan bahwa : “...bukti ilmiah atau digital evidence yang kekuatan pembuktiannya sangat akurat dan tingkat kebenarannya sangat tinggi (kecuali terjadi rekayasa alat bukti) dan sehingga kalau sekiranya perkara ini diajukan ke persidangan hasilnya akan sama... dst". ${ }^{13}$ Dengan demikian,

${ }^{9}$ Ibid.

${ }^{10}$ Ibid.

11 Ibid.

${ }^{12}$ Setidaknya ada enam ahli di bidang psikologi, teknologi informatika, dan forensik yang dilibatkan dalam penyidikan ini yang kesemuanya adalah untuk membuktikan secara ilmiah. Sumber: Harian Kompas, "Investigasi Ilmiah Menjadi Petunjuk Ungkap Kasus Mirna”, diterbitkan pada hari Senin, tanggal 01 Februari 2016.

${ }^{13}$ Putusan Mahkamah Agung RI No. 664 K/Pid.Sus/2014, tertanggal 29 Oktober 2014 An. Terdakwa Axsa Vanesia Geslauw, hlm. 8-9, terdapat perbedaan pendapat (Dissenting Opinion) mengenai penggunaan scientific evidence dari Hakim Anggota I, Surya Jaya, dengan pendapat sebagai berikut : "Bahwa alasan kasasi Jaksa Penuntut Umum dapat dibenarkan, Judex Factie telah salah menerapkan hukum dalam hal menyatakan Terdakwa tidak terbukti secara sah dan meyakinkan bersalah melakukan tindak pidana sebagaimana dalam dakwaan Jaksa Penuntut Umum, dengan alasan : Bahwa Terdakwa dan ibunya menuduh dan melaporkan Saksi Korban Stevanus Wattimena telah menghamili Terdakwa Axsa. Pada tanggal 19 Januari 2010 Terdakwa melaporkan Saksi Korban Stevanus ke kantor polisi. Saksi Korban Stevanus kemudian diperiksa sebagai Tersangka. Setelah dilakukan pemeriksaan DNA, Saksi Korban Stevanus dan Test DNA Anak Terdakwa, hasil pemeriksaan menunjukkan bahwa pemeriksaan DNA Anak Terdakwa berbeda dan tidak sama hasil pemeriksaan DNA Saksi Korban Stevanus. Sehingga berdasarkan hasil pemeriksaan DNA tersebut tidak sama atau berbeda, maka pihak Kepolisian berpendapat penyidikan atas kasus Saksi Stevanus atas tuduhan 
Fakultas Hukum Universitas Komputer Indonesia

Vol. 3 No. 2 Juli 2021

bukti ilmiah atau digital evidence telah diakui dalam peradilan di Indonesia sebagai salah satu bukti yang dapat digunakan hakim untuk menghukum seorang terdakwa sesuai Pasal 183 KUHAP.

Selain itu, terdapat tindak pidana ujaran kebencian saat ini yang semakin menjadi perhatian masyarakat nasional maupun internasional seiring dengan meningkatnya kepedulian terhadap perlindungan hak asasi manusia. Wadah terbesar yang memudahkan munculnya tindak pidana ujaran kebencian adalah melalui media sosial. Media sosial tersebut, seperti: facebook, twitter, instagram, dan jaringan sosial lainnya. Penyebaran ujaran kebencian di media sosial bertujuan untuk menimbulkan rasa kebencian atau permusuhan antara individu dan/atau kelompok masyarakat tertentu berdasarkan atas suku, agama, ras, dan antar golongan (SARA) yang mampu mengakibatkan perubahan besar dan sering digunakan untuk kepentingan politik beberapa kalangan. ${ }^{14}$

Berdasarkan Surat Edaran Kapolri No. SE/06/X/2015 tentang Penanganan Ujaran Kebencian (Hate Speech) menunjukkan bahwa tindak pidana ujaran kebencian adalah suatu bentuk kejahatan yang tidak dapat dipandang sebelah mata, mengingat bentuk ujaran kebencian dan media penyebarannya yang kompleks serta akibat yang ditimbulkannya dapat mengganggu keutuhan bangsa dan negara. ${ }^{15}$

Pengaturan hukum mengenai tindak pidana ujaran kebencian di Indonesia memang belum secara khusus diatur dan jelas seperti di negara-negara lain. Namun beberapa instrument Hak Asasi Manusia dan Undang-Undang yang tersedia telah memberikan payung hukum terhadap permasalahan ini, yaitu: Undang-Undang No. 11 Tahun 2008 tentang Informasi dan Transaksi

menghamili Terdakwa Axsa dihentikan penyidikannya (SP3) di Polda Maluku karena tidak cukup bukti untuk diperkarakan di muka pengadilan.

Bahwa berhubung dengan hal tersebut, Saksi Korban Stevanus kemudian melaporkan balik Terdakwa Axsa ke kantor polisi dengan dasar telah melakukan perbuatan fitnah dan pencemaran nama baik Saksi Stevanus. Di dalam beberapa media surat kabar misalnya Surat Kabar Maluku Ekspres tanggal 23 Mei 2010 telah diberitakan bahwa Saksi Korban Stevanus telah menghamili Terdakwa Axsa. Padahal, kemudian ternyata laporan dan pengaduan yang dilakukan Terdakwa Axsa adalah merupakan tuduhan yang tidak benar dan tidak mendasar, mengada-ada alias fitnah belaka. Bahwa sesuai ketentuan Pasal 314 ayat (3) Kitab Undang-Undang Hukum Pidana berhubung karena tuduhan yang sifatnya fitnah telah dinyatakan oleh Penyidik tidak cukup bukti untuk dilanjutkan prosesnya ke persidangan, maka berdasarkan ayat (2) pasal ini menjadi bukti sempurna dan dasar bagi Saksi Korban Stevanus bahwa apa yang dituduhkan Terdakwa kepadanya adalah tidak benar. Sehingga, Terdakwa harus bertanggungjawab atas resiko dan akibat hukum yang ditimbulkan atas tuduhan dan fitnah yang ditujukan dan dialamatkan pada Saksi Korban Stevanus.

Bahwa pertimbangan Judex Factie dalam membebaskan Terdakwa adalah keliru sebab didasarkan pada alasan bahwa Majelis Judex Factie berpendapat bahwa penghentian perkara Saksi Korban Stevanus dengan dasar dikeluarkannya SP3 bukanlah merupakan perbuatan yang merusak kehormatan atau nama baik seseorang Stevanus. Bahwa penghentian perkara dengan alasan SP3 secara hukum tidak dapat disetarakan atau disamakan kedudukannya dengan putusan bebas pengadilan untuk dijadikan bukti sempurna menghukum Terdakwa Axsa sebagaimana dimaksud Pasal 314 ayat (2) KUHPidana. Namun, karena alasan penghentian penyidikan didasarkan pada alat bukti ilmiah atau scientific evidence yang kekuatan pembuktiannya sangat akurat dan tingkat kebenarannya sangat tinggi (kecuali terjadi rekayasa alat bukti) dan sehingga kalau sekiranya perkara ini diajukan ke persidangan hasilnya akan sama, berdasarkan alasan tersebut, maka hal ini dapat menjadi dasar dan bukti sempurna untuk menyatakan apa yang dituduhkan Terdakwa Axsa adalah tidak benar. Sehingga, Terdakwa Axsa dipersalahkan melakukan tindak pidana pencemaran nama baik. Bahwa berdasarkan pada fakta dan alasan pertimbangan tersebut, Hakim Anggota I berpendapat bahwa Terdakwa Axsa terbukti melakukan pencemaran atau fitnah terhadap Saksi Stevanus sebab dengan tidak terbuktinya tuduhan Terdakwa terhadap Saksi Korban menjadi dasar untuk menyalahkan Terdakwa Axsa telah melakukan perbuatan melanggar Pasal 310 ayat (1) KUHPidana".

14 Gusti Ayu Made Gita Permatasari, "Tinjauan Yuridis Mengenai Pengaturan dan Pertanggungjawaban Pidana Terhadap Tindak Pidana Ujaran Kebencian di Media Sosial”, Journal Ilmu Hukum Vol. 07 No. 03, Mei 2018, hlm. 4.

${ }^{15}$ Ibid. 
Vol. 3 No. 2 Juli 2021

Elektronik sebagaimana telah diubah dengan Undang-Undang No. 19 Tahun 2016 tentang Perubahan Atas Undang-Undang No. 11 Tahun 2008 tentang Informasi dan Transaksi Elektronik (selanjutnya disebut "UU ITE").

Adapun objek penelitian ini adalah Putusan Pengadilan Negeri Medan No. 3168/Pid.Sus/2018/PN.Mdn., tertanggal 23 Mei 2019 mengenai penggunaan bukti digital (digital evidence) An. Terdakwa Himma Dewiyana Lubis Alias Himma, yang amarnya berbunyi, sebagai berikut: ${ }^{16}$

1. "Menyatakan Terdakwa Himma Dewiyana Lubis Als Himma, ST., M.Hum., telah terbukti secara sah dan meyakinkan bersalah melakukan "Tindak Pidana Dengan Sengaja dan Tanpa Hak Menyebarkan Informasi Yang Ditujukan Untuk Menimbulkan Rasa Kebencian atau Permusuhan Individu dan atau Kelompok Masyarakat Tertentu Berdasarkan Atas Suku, Agama, Ras, dan Antar Golongan (SARA);

2. Menjatuhkan pidana terhadap Terdakwa oleh karena itu dengan pidana penjara selama 1 (satu) tahun dan denda sejumlah Rp. 10.000.000,- (sepuluh juta rupiah) dengan ketentuan apabila Terdakwa tidak membayar denda, maka diganti dengan pidana kurungan selama 3 (tiga) bulan;

3. Menetapkan pidana tersebut tidak perlu dijalankan kecuali jika di kemudian hari ada putusan hakim yang menentukan lain disebabkan karena terpidana melakukan tindak pidana sebelum lewat masa percobaan 2 (dua) tahun;

4. Menetapkan masa penangkapan dan penahanan yang telah dijalani Terdakwa dikurangkan seluruhnya dari pidana yang dijatuhkan;

5. Menetapkan barang bukti, berupa :

a. 1 (satu) unit Handphone Iphone 6S warna silver;

b. 1 (satu) buah SimCard Mentari No. 081533807888 ;

c. 1 (satu) buah Flashdisk Toshiba $4 \mathrm{~Gb}$ yang berisikan screenshoot facebook Himma Dewiyana dan file akun Facebook Himma Dewiyana;

d. 3 (tiga) screenshoot Facebook akun Himma Dewiyana;

Dimusnahkan;

6. Membebankan kepada Terdakwa untuk membayar biaya perkara sebesar Rp. 5.000,(lima ribu rupiah)".

Perkara tersebut di atas, diajukan ke muka persidangan dengan Surat Dakwaan Register Perkara No. PDM-903/EP/08/2018, tertanggal 28 November 2018 yang dibacakan di depan persidangan pada hari Rabu, tanggal 09 Januari 2019 dengan dakwaan tunggal, sebagai berikut: "Perbuatan Terdakwa diatur dan diancam Pidana melanggar Pasal 28 ayat (2) Jo Pasal 45A ayat (2) UU RI No. 19 Tahun 2016 tentang Perubahan Atas UU RI No. 11 Tahun 2008 tentang ITE". ${ }^{17}$

Kepastian yang diperlukan pada pembuktian dalam perkara pidana berbeda dengan tingkat kepastian pada perkara perdata. Pada perkara pidana diperlukan tingkat kepastian yang mendekati seratus persen (beyond reasonable doubt) atau sampai tidak ada lagi keraguan yang beralasan, sesuai dengan keinginan filosofis hukum pidana untuk mencapai kebenaran materil, khususnya pada pidana dengan ancaman hukuman yang tinggi. Sedangkan, perkara perdata lebih menggunakan pembandingan kekuatan bukti kedua pihak atau balancing of evidence, sehingga tingkat

16 Sistem Informasi Penelusuran Perkara Pengadilan Negeri Medan, "Perkara Pidana Khusus No. 3168/Pid.Sus/2018/PN.Mdn., An. Terdakwa Himma Dewiyana Lubis Alias Himma, ST., M.Hum”, http://sipp.pn-medankota.go.id/index.php/detil perkara., diakses pada hari Sabtu, tanggal 26 Oktober 2019.

${ }^{17}$ Putusan Pengadilan Negeri Meulaboh No. 53/Pid.Sus-2014/PN.MBO, tertanggal 28 Januari 2016 An. Para Terdakwa Eddy Sutjahyo Busiri,dkk, hlm. 20-24. 
Vol. 3 No. 2 Juli 2021

kepastiannya bervariasi dari "precautionary principle, more likely than not, clear and convincing, beyond reasonable doubt", hingga "irrefutable". 18

Dalam masalah ilmiah dan teknis, para hakim banyak mengacu kepada keterangan ahli sebagai individu. Sistem hukum memang telah memiliki hukum pembuktian yang mengatur tentang aturan penerimaan (adminisibilitas) keterangan ahli. Tetapi hukum pembuktian tidak mengatur tentang aturan, metode, prosedur, dan bukti ilmiah seperti apa yang seharusnya diterima di sidang pengadilan. Keterangan ahli didasarkan kepada standar pembuktian kedokteran yang mungkin saja berbeda dari standar pembuktian hukum sebagaimana diuraikan di atas. Pengadilan harus tetap memiliki kewenangan penuh untuk menerima atau menolak bukti ilmiah yang diajukan. Pada umumnya, "visum et repertum" ataupun keterangan ahli dapat diterima sebagai alat bukti sah, namun tidak berarti bahwa substansi keterangannya dapat langsung diterima sebagai bukti. ${ }^{19}$

Hambatan yang dihadapi oleh aparat penegak hukum saat ini, masih minimnya aparat penegak hukum yang memahami dan mengerti tentang alat bukti ilmiah. Hal ini kerap menjadi hambatan mengingat belum adanya kesepahaman diantara para aparat penegak hukum, baik dari pihak Kepolisian, Kejaksaan/KPK, Pengadilan, maupun Advokat yang juga telah diakui kedudukannya sebagai aparat penegak hukum. Selain itu, minimnya perhatian pemerintah dalam hal peningkatan kualitas aparat penegak hukum yang ada di Indonesia, seakan-akan pemerintah membiarkan masing-masing instansi untuk meningkatkan sumber dayanya sendiri tanpa terkoordinir dengan baik.

Berdasarkan uraian latar belakang di atas, maka permasalahan yang timbul dalam penelitian ini dapat dirumuskan, yaitu bagaimana penggunaan bukti digital (digital evidence) dalam perkara tindak pidana ujaran kebencian di media sosial? dan bagaimana analisis yuridis bukti digital (digital evidence) dalam pembuktian perkara tindak pidana ujaran kebencian pada Putusan Pengadilan Negeri Medan No. 3168/Pid.Sus/2018/PN.Mdn?

\section{METODE PENELITIAN}

Penelitian ini adalah penelitian hukum normatif. ${ }^{20}$ Sifat penelitian adalah deskriptif analisis. ${ }^{21}$ Jenis data yang digunakan adalah data sekunder yang bersumber dari bahan hukum primer, sekunder, dan tertier. ${ }^{22}$ Selanjutnya juga digunakan data primer untuk mendukung data

${ }^{18}$ Miller DW dan Miller CG, "On Evidence, Medical and Legal”, Journal of American Physicians and Surgeons, Vol. 10, No. 3, 2005, menyatakan bahwa : "Pada umumnya pengadilan perdata di Inggris atau negara Common Law dapat memutus perkara cukup dengan tingkat kepastian more likely than not atau berarti lebih dari 50\%. Sedangkan, di Amerika hakim harus menggunakan tingkat kepastian clear and conviction pada kasus yang memerlukan kecermatan, seperti pada pengasuhan anak, kesepakatan non sukarela, keputusan withdrawal of life support pada pasien koma, penentuan sikap tindak (frame of mind) yang dapat dihukum pada kasus fraud, dan pada pendisiplinan profesi advokat dan dokter".

${ }^{19}$ Budi Sampurna, "Bukti Medis Versus Bukti Hukum”, Indonesian Journal of Legal and Forensic Sciences, Vol. 2, No. 2, 2012, hlm. 29.

20 Penelitian hukum normatif, yaitu menganalisis data didasarkan pada asas-asas hukum dan perbandingan-perbandingan hukum yang ada dalam masyarakat. Lihat: Soerjono Soekanto, Penelitian Hukum Normatif : Suatu Tinjauan Singkat, (Jakarta : Raja Grafindo Persada, 2001), hlm. 6.

21 Penelitian hukum deskriptif bersifat pemaparan dan bertujuan untuk memperoleh gambaran (deskripsi) lengkap tentang keadaan hukum yang berlaku di tempat tertentu dan pada saat tertentu, atau mengenai gejala yuridis yang ada, atau peristiwa hukum tertentu yang terjadi dalam masyarakat. Lihat : Peter Mahmud Marzuki, Penelitian Hukum, (Jakarta : Prenada Media Group, 2007), hlm. 93-95.

${ }^{22}$ Data sekunder adalah data yang diperoleh dengan mempelajari bahan-bahan pustaka yang berupa peraturan perundang-undangan dan literatur-literatur lainya yang saling berhubungan dengan permasalahan yang dibahas. Lihat : Mukti Fajar dan Yulianto Achmad, Dualisme Penelitian Hukum-Normatif dan Empiris, (Yogyakarta : Pustaka Pelajar, 2015), hlm. 156. 
Vol. 3 No. 2 Juli 2021

sekunder. Data sekunder dikumpulkan dengan teknik studi kepustakaan (library research). ${ }^{23}$ Selanjutnya, data-data tersebut dianalisa dengan menggunakan metode analisa kualitatif. ${ }^{24}$

\section{HASIL PENELITIAN \& PEMBAHASAN}

\section{Penggunaan Bukti Digital (Digital Evidence) Dalam Perkara Tindak Pidana Ujaran Kebencian} Melalui Media Sosial

\section{A. Ketentuan Penyebaran Kebencian (Haatzaai Artikelen) Dalam KUHP}

Kitab Undang-Undang Hukum Pidana (KUHP) memiliki beberapa pasal yang dikenal sebagai pasal-pasal penyebaran kebencian (haatzaai artikelen), yaitu Pasal 154 tentang barangsiapa di muka umum menyatakan perasaan permusuhan, kebencian atau penghinaan terhadap Pemerintah Indonesia, Pasal 155 tentang penyiaran dari tindak pidana Pasal 154, dan Pasal 156 tentang barangsiapa di muka umum menyatakan perasaan permusuhan, kebencian atau penghinaan terhadap suatu atau beberapa golongan rakyat Indonesia. Pasal-pasal tersebut dengan tegas melarang pernyataan yang antara lain berupa pernyataan perasaan kebencian terhadap Pemerintah Indonesia (Pasal 154 dan Pasal 155) atau suatu/beberapa golongan rakyat Indonesia (Pasal 156). ${ }^{25}$

Pasal 154 dan Pasal 155 KUHP kemudian telah diputuskan sebagai bertentangan dengan Undang-Undang Dasar Negara Republik Indonesia Tahun 1945 dan karenanya tidak mempunyai kekuatan hukum mengikat oleh Putusan Mahkamah Konstitusi No. 6/PUU-V/2007. ${ }^{26}$ Dasar pertimbangan Mahkamah Konstitusi dalam putusannya tersebut, yaitu: “... bahwa ketentuan Pasal 154 dan Pasal 155 KUHP, di satu pihak, tidak menjamin adanya kepastian hukum sehingga bertentangan dengan Pasal 28D ayat (1) UUD 1945, di pihak lain, sebagai konsekuensinya, juga secara tidak proporsional menghalang-halangi kemerdekaan untuk menyatakan pikiran dan sikap serta kemerdekaan menyampaikan pendapat sehingga bertentangan dengan Pasal 28 dan Pasal 28E ayat (2) dan ayat (3) UUD 1945". ${ }^{27}$

Pertimbangan Mahkamah Konstitusi, yaitu: ${ }^{28}$

1. "Pasal 154 dan 155 KUHPidana tidak menjamin adanya kepastian hukum (bertentangan dengan Pasal 28D ayat (1) UUD 1945), dan

2. Secara tidak proporsional menghalang-halangi kemerdekaan untuk menyatakan pikiran dan sikap serta kemerdekaan menyampaikan pendapat (bertentangan dengan Pasal 28 dan 28E Ayat (2) dan Ayat (3) UUD 1945).

Mahkamah telah menggunakan dasar pertimbangan ini untuk menjatuhkan putusan bahwa Pasal 154 dan Pasal 155 KUHPidana bertentangan dengan UUD 1945 dan karenanya tidak mempunyai kekuatan hukum mengikat".

Putusan Mahkamah Konstitusi No. 6/PUU-V/2007 menimbulkan atau memperkuat pandangan umum bahwa di Indonesia telah diakui dan dilindungi kebebasan menyatakan pendapat.

${ }^{23}$ Studi kepustakaan adalah segala usaha yang dilakukan untuk menghimpun informasi yang relevan dengan topik atau masalah yang akan atau sedang diteliti. Informasi itu dapat diperoleh dari buku-buku ilmiah, laporan penelitian, karangan-karangan ilmiah, tesis dan disertasi, peraturan-peraturan, ketetapan-ketetapan, buku tahunan, ensiklopedia, dan sumber-sumber bahan hukum lainnya. Lihat : Mestika Zed, Metode Penelitian Kepustakaan, Ed. Ke-2, (Jakarta : Yayasan Obor Indonesia, Januari 2008), hlm. 1.

${ }^{24}$ Dilihat dari tujuan analisis, maka ada 2 (dua) hal yang ingin dicapai dalam analisis data kualitatif, yaitu : 1) Menganalisis proses berlangsungnya suatu fenomena hukum dan memperoleh suatu gambaran yang tuntas terhadap proses tersebut; dan 2) Menganalisis makna yang ada di balik informasi, data, dan proses suatu fenomena. Lihat : Burhan Bungin, Penelitian Kualitatif : Komunikasi, Ekonomi, Kebijakan Publik, dan Ilmu Sosial Lainnya, (Jakarta : Kencana, 2009), hlm. 153.

${ }^{25}$ Mangantibe, Veisy. "Ujaran Kebencian dalam Surat Edaran Kapolri Nomor: SE/6/x/2015 Tentang Penanganan Ucapan Kebencian (Hate Speech)." Lex Crimen, Vol. 5, No. 1, (2016).

${ }^{26}$ Putusan Mahkamah Konstitusi No. 6/PUU-V/2007, tertanggal 17 Juli 2007.

${ }^{27}$ Ibid.

${ }^{28}$ Ibid. 
Vol. 3 No. 2 Juli 2021

Orang-orang dapat dengan bebas menyatakan pendapat dan media massa juga bebas untuk memuat berita dengan tidak perlu takut lagi diperlakukan sebagai pelaku tindak pidana penyebaran kebencian. Oleh karenanya merupakan hal yang cukup mengagetkan masyarakat ketika dipublikasikan bahwa Kepala Kepolisian Negara Republik Indonesia (Kapolri) telah menerbitkan suatu produk hukum yang berkenaan dengan ancaman pidana terhadap apa yang disebut ujaran kebencian atau hate speech.

Adanya produk hukum yang diterbitkan Kapolri tentang ujaran kebencian (hate speech) telah menimbulkan pertanyaan-pertanyaan antara lain mengenai lingkup cakupan dan kedudukan dari ujaran kebencian yang dikemukakan dalam produk hukum tersebut.

\section{B. Pengaturan dan Pertanggungjawaban Tindak Pidana Ujaran Kebencian Melalui Media Massa}

Kemudahan dalam menyampaikan pikiran secara lisan dan tulisan dewasa ini berjalan seiring dengan semakin berkembangnya teknologi informasi. Perkembangan teknologi informasi sudah sangat canggih, cepat dan mudah, sehingga menjadi gaya hidup (life style) bagi masyarakat di seluruh dunia tidak terkecuali Indonesia yang juga terkena pengaruh perkembangan teknologi informasi di era globalisasi ini. Salah satu pemanfaatan teknologi informatika dengan munculnya berbagai macam situs jejaring sosial ini menyebar luas ke berbagai macam kalangan anak-anak, mahasiswa, ibu rumah tangga, ekonomi atas sampai ekonomi bawah dan masih banyak yang lainnya dapat menggunakan situs jejaring sosial untuk kebutuhan masing-masing pengguna. ${ }^{29} \mathrm{Hal}$ ini mengakibatkan setiap orang dapat berekspresi dan bebas mengeluarkan pendapat, kritik ataupun saran melalui jejaring sosial yang dimiliki. Penggunaan media sosial secara meluas ini memiliki dampak yang diibaratkan sepertia dua sisi mata uang. Di satu sisi dapat memberi dampak positif pada bidang sosial, pendidikan, politik, ekonomi dan sebagainya. Namun di sisi lain dapat menyebabkan munculnya jenis kejahatan baru.

Secara khusus, perkembangan teknologi komputer dan internet memberikan implikasiimplikasi yang signifikan terhadap pengaturan atau pembentukan regulasi dalam ruang siber dan hukum siber serta terhadap perkembangan kejahatan dalam dunia maya (cyberspace), (cybercrimes). ${ }^{30}$ Salah satu dampak negatif yang sering terjadi dengan semakin mudahnya komunikasi dan bertukar informasi melalui media sosial antara sesama pengguna adalah mudahnya suatu pendapat yang memiliki muatan penghinaan, pencemaran nama baik atau ujaran kebencian (Hate Speech) tersebar dan di akses oleh semua orang.

Tindak pidana ujaran kebencian (Hate Speech) saat ini semakin menjadi perhatian masyarakat nasional maupun internasional seiring dengan meningkatnya kepedulian terhadap perlindungan hak asasi manusia. Wadah terbesar yang memudahkan munculnya tindak pidana ujaran kebencian adalah melalui media sosial seperti facebook, twitter, instagram dan jaringan sosial lainnya. Penyebaran ujaran kebencian (Hate Speech) di media sosial bertujuan untuk menimbulkan rasa kebencian atau permusuhan antara individu dan/atau kelompok masyarakat tertentu berdasarkan atas suku, agama, ras dan antargolongan (SARA) yang mampu mengakibatkan perubahan besar dan sering digunakan untuk kepentingan politik beberapa kalangan. Hal tersebut menjadi salah satu alasan dikeluarkannya Surat Edaran Nomor SE/06/X/2015 tentang Penanganan Ujaran Kebencian (Hate Speech) yang ditandatangani oleh Kapolri Badrodin Haiti. ${ }^{31}$ Tindak pidana ujaran kebencian (Hate Speech) adalah suatu bentuk kejahatan yang tidak bisa dipandang sebelah mata mengingat

${ }^{29}$ Budi Suhariyanto, Tindak Pidana Teknologi Informasi (Cybercrime), (Jakarta: Raja Grafindo Persada, 2014), hlm. 2.

${ }^{30}$ Josua Sitompul, Cyberspace, Cybercrimes, Cyberlaw: Tinjauan Aspek Hukum Pidana, (Jakarta: Tatanusa, 2012), hlm. 26.

${ }^{31}$ Mangantibe, Veisy. Op.cit. 
Vol. 3 No. 2 Juli 2021

bentuk ujaran kebencian dan media penyebarannya yang kompleks serta akibat yang ditimbulkannya dapat mengganggu keutuhan bangsa dan negara.

Pengaturan hukum mengenai tindak pidana ujaran kebencian (Hate Speech) di Indonesia memang belum diatur secara khusus dan jelas seperti di negara-negara lain. Namun beberapa instrumen HAM dan undang-undang yang tersedia telah memberikan payung hukum terhadap permasalahan ini. $^{32}$

Ujaran kebencian (Hate Speech) adalah tindakan berupa lisan maupun tulisan yang dilakukan oleh individu atau kelompok dalam bentuk provokasi atau hasutan kepada individu atau kelompok yang lain dalam berbagai aspek seperti ras, agama, warna kulit, gender, cacat, orientasi seksual, kewarganegaraan dan lain sebagainya. Dalam arti hukum, Hate Speech adalah perkataan, perilaku, tulisan ataupun pertunjukan yang dilarang karena dapat memicu terjadinya tindakan kekerasan dan kegaduhan dalam kehidupan bermasyarakat.

\section{Lingkup Ujaran Kebencian Dalam Surat Edaran Kapolri No. SE/6/X/2015 tentang Penanganan Ujaran Kebencian (Hate Speech)}

Lingkup dari ujaran kebencian dikemukakan dalam angka 2 huruf f Surat Edaran Kapolri No. SE/6/X/2015 tentang Penanganan Ujaran Kebencian (Hate Speech).

Berdasarkan Surat Edaran Kapolri Nomor SE/06/X/2015 tentang Ujaran Kebencian (Hate Speech) disebutkan tentang Ujaran Kebencian (Hate Speech) dapat berupa tindak pidana yang diatur dalam KUHP dan ketentuan-ketentuan pidana lainnya di luar KUHP, yang berbentuk: 1. "Penghinaan; 2. Pencemaran nama baik; 3. Penistaan; 4. Perbuatan tidak menyenangkan; 5. Memprovokasi; 6. Menghasut; 7. Menyebarkan berita bohong”.

Tindakan yang disebut diatas memiliki dampak akan terjadinya penghilangan nyawa, kekerasan, diskriminasi, atau konflik sosial. Tujuan dari ujaran kebencian sebagaimana yang disebutkan di atas adalah untuk menghasut dan menyulut kebencian terhadap individu dan/atau kelompok masyarakat dalam berbagai komunitas. Dalam huruf (h) Surat Edaran tersebut, Ujaran Kebencian (Hate Speech) dapat dilakukan melalui berbagai media, antara lain: ${ }^{33}$ 1. "Dalam orasi kegiatan kampanye; 2. Spanduk atau banner; 3. Jejaring media sosial; 4. Penyampaian pendapat di muka umum (demonstrasi); 5. Ceramah keagamaan; 6. Media masa cetak atau elektronik; 7. Pamflet"

Penegakan hukum atas dugaan terjadinya tindak pidana ujaran kebencian berdasarkan Surat Edaran Kapolri No. SE/06/X/2015 tentang Ujaran Kebencian (Hate Speech) mengacu pada ketentuan: 1. "Pasal 156 KUHP; 2. Pasal 157 KUHP; 3. Pasal 310 KUHP; 4. Pasal 311 KUHP; 5. Pasal 28 ayat (2) jis. Pasal 45 ayat (2) Undang-Undang No. 11 Tahun 2008 tentang Informasi dan Transaksi Elektronik; 6. Pasal 16 Undang-Undang No. 40 Tahun 2008 tentang Penghapusan Diskriminasi Ras dan Etnis".

Lingkup ujaran kebencian (hate speech) dalam Surat Edaran Kapolri No. SE/6/X/2015 adalah keseluruhan perbuatan yang bersifat menghina, mencemarkan nama baik, menista, perbuatan tidak menyenangkan, memprovokasi, menghasut atau menyebarkan berita bohong, baik dalam KUHP maupun luar KUHP, yang:

a. Bertujuan atau berdampak pada tindak diskriminasi, kekerasan, penghilangan nyawa dan/atau konflik sosial; serta

b. Bertujuan menghasut dan menyulut kebencian terhadap individu dan/atau kelompok masyarakat dalam berbagai komunitas yang dibedakan dari aspek: suku, agama, aliran keagamaan, keyakinan/kepercayaan, ras, antargolongan, warna kulit, etnis, gender, kaum difabel (cacat), orientasi seksual.

\footnotetext{
${ }^{32}$ Gusti Ayu Made Gita Permatasari dan Komang Pradnyana Sudibya, Op.cit., hlm. 3.

${ }^{33}$ Ibid.
} 
Vol. 3 No. 2 Juli 2021

\section{Kedudukan Surat Edaran Kapolri No. SE/6/X/2015 tentang Penanganan Ujaran Kebencian (Hate Speech)}

Surat Edaran Kapolri Nomor: SE/6/X/2015 dalam angka 1 menunjuk bahwa sebagai rujukan pembuatan surat edaran ini, yaitu:
a. "Kitab Undang-Undang Hukum Pidana
b. Undang-Undang No. 39 Tahun 1999 tentang Hak Asasi Manusia
c. Undang-Undang No. 2 Tahun 2002 tentang Kepolisian Negara Republik Indonesia
d. Undang-Undang No. 11 Tahun 2005 tentang Ratifikasi Konvensi Internasional Hak-hak Ekonomi, Sosial dan Budaya
e. Undang-Undang No. 12 Tahun 2005 tentang Ratifikasi Konvensi Internasional Hak-hak Sipil dan Politik
f. Undang-Undang No. 11 Tahun 2008 tentang Informasi dan Transaksi Elektronik
g. Undang-Undang No. 40 Tahun 2008 tentang Penghapusan Diskriminasi Ras dan Etnis
h. Undang-Undang No. 7 Tahun 2012 tentang Penanganan Konflik Sosial
i. Perkap Kapolri No. 8 Tahun 2009 tentang Implementasi Prinsip dan Standar Hak Asasi Manusia dalam Penyelenggaraan Tugas Kepolisian Negara Republik Indonesia
j. Perkap Kapolri No. 8 Tahun 2013 tentang Teknis Penanganan Konflik Sosial”.

Selanjutnya, dalam Surat Edaran Kapolri Nomor: SE/6/X/2015 pada angka 2 huruf a dinyatakan bahwa: "ujaran kebencian dapat berupa tindak pidana yang diatur dalam Kitab UndangUndang Hukum Pidana (KUHP) dan ketentuan pidana lainnya di luar KUHP...”.

Dengan demikian, Surat Edaran Kapolri tersebut menunjuk pada tindak-tindak pidana yang sudah ada, baik yang ada dalam KUHP maupun tindak pidana di luar KUHP seperti tindak pidana yang ada dalam Undang-Undang No. 11 Tahun 2008 tenang Informasi dan Transaksi Elektronik. Surat edaran ini tidak membuat kaidah-kaidah atau norma-norma baru dalam bidang hukum pidana.

Selain itu, bentuk produk hukum ini adalah suatu Surat Edaran, yaitu Surat Edaran Kapolri, bukan suatu Peraturan Kapolri. Dilihat dari sudut ini, Surat Edaran Kapolri No. SE/6/X/2015 adalah sebagai suatu instruksi internal dalam lingkungan kepolisian yang berada pada tingkat operasional kepolisian untuk penanganan praktis perbuatan-perbuatan yang dipandang sebagai ujaran kebencian sepanjang perbuatan itu memiliki tujuan atau bisa berdampak pada tindak diskriminasi, kekerasan, penghilangan nyawa, dan/atau konflik sosial.

Tingkat operasional dari surat edaran ini tampak dalam tata cara penanganan yang diatur dalam surat edaran, yaitu:

1. Melakukan tindakan preventif, dimana tindakan preventif antara lain "setiap anggota Polri agar memiliki pengetahuan dan pemahaman mengenai bentuk-bentuk ujaran kebencian yang timbul di masyarakat" dan agar "mengefektifkan dan mengedepankan fungsi intelijen untuk mengetahui kondisi riil di wilayah-wilayah yang rawan konflik".

2. Apabila tindakan preventif sudah dilakukan oleh anggota Polri namun tidak menyelesaikan masalah yang timbul akibat tindakan ujaran kebencian, maka penyelesaian dapat dilakukan melalui:

a. Penegakan hukum atas dugaan terjadinya tindak pidana ujaran kebencian dengan mengacu pada ketentuan.

b. Dalam hal telah terjadi konflik sosial yang dilatarbelakangi ujaan kebencian dalam penanganannya tetap berpedoman pada:

1) Undang-Undang No. 7 Tahun 2012 tentang Penanganan Konflik Sosial; dan

2) Perkap Kapolri No. 8 Tahun 2013 tentang Teknis Penanganan Konflik Sosial.

Kedudukan Surat Kapolri No. SE/6/X/2015 adalah suatu surat edaran sebagai suatu instruksi internal dalam lingkungan kepolisian yang berada pada tingkat operasional kepolisian untuk penanganan praktis perbuatanperbuatan yang dipandang sebagai ujaran kebencian, sepanjang perbuatan itu memiliki tujuan atau bisa berdampak pada tindak diskriminasi, kekerasan, 
Vol. 3 No. 2 Juli 2021

penghilangan nyawa, dan/atau konflik sosial; sehingga surat edaran ini tidak membuat kaidah (norma) baru dalam hukum pidana melainkan menunjuk tindak pidana yang sudah ada sebelumnya. Perlu publikasi lebih luas untuk menekankan Surat Edaran Kapolri Nomor: SE/6/X/2015 merupakan instruksi internal yang berada pada tingkat operasional kepolisian, bukan merupakan pembentukan kaidah (norma) baru.

Istilah "perbuatan tidak menyenangkan" tidak perlu dicantumkan dalam Surat Edaran Kapolri No. SE/6/X/2015 karena tindak pidana tersebut oleh Putusan Mahkamah Konstitusi No. 1/PUUXI/ 2013, tanggal 16 Januari 2014 telah dinyatakan bertentangan dengan UUD 1945 dan tidak mempunyai kekuatan hukum mengikat.

\section{Pertanggungjawaban Tindak Pidana Ujaran Kebencian Melalui Media Sosial}

Pertanggungjawaban pidana adalah pertanggungjawaban orang terhadap tindak pidana yang dilakukannya. Tegasnya, yang dipertanggungjawabkan orang itu adalah tindak pidana yang dilakukannya. Dengan demikian, terjadinya pertanggungjawaban pidana karena telah ada tindak pidana yang dilakukan oleh seseorang. ${ }^{34}$

Pada hakikatnya pertanggungjawaban selalu dimintakan terhadap individu yang dianggap bersalah dalam terjadinya suatu tindak pidana. Pertanggungjawaban pidana pada dasarnya dapat dipertanggungjawabkan kepada diri seorang pelaku tindak pidana harus memenuhi 4 (empat) unsur persyaratan, sebagai berikut: ${ }^{35}$

1. "Ada suatu tindakan (commission atau omission) oleh si pelaku

2. Yang memenuhi rumusan-rumusan delik dalam Undang-Undang

3. Tindakan itu bersifat melawan hukum atau unlawful

4. Pelakunya harus bisa dipertanggungjawabkan".

Bentuk pertanggungjawaban pidana terhadap pelaku tindak pidana ujaran kebencian di media sosial berdasarkan asas lex specialis derogat legi generali mengacu kepada ketentuan Pasal 28 ayat (2) jis. Pasal 45A ayat (2) Undang-Undang No. 19 Tahun 2016 tentang Perubahan Atas Undang-Undang No. 11 Tahun 2008 tentang Informasi dan Transaksi Elektronik.

Unsur-unsur Tindak Pidana ITE dalam Pasal 28 ayat (2) yaitu: ${ }^{36}$

1. "Kesalahan : dengan sengaja

2. Melawan hukum : tanpa hak

3. Perbuatan : menyebarkan

4. Objek : Informasi

5. Tujuan : untuk menimbulkan rasa kebencian atau permusuhan individu dan/atau kelompok masyarakat tertentu berdasarkan atas suku, agama, ras, dan antar golongan (SARA)".

Pertanggungjawaban pidana terhadap orang yang terbukti memenuhi unsur-unsur tindak pidana dalam Pasal 28 ayat (2) UU ITE berdasarkan Pasal 45A ayat (2) UU ITE adalah pidana penjara maksimal 6 tahun dan/atau pidana denda paling banyak Rp. 1.000.000.000,00 (satu miliar rupiah).

\section{Pembuktian Tindak Pidana Ujaran Kebencian di Media Sosial}

${ }^{34}$ Chairul Huda, Dari Tiada Pidana Tanpa Kesalahan Menuju Kepada Tiada Pertanggungjawaban Pidana Tanpa Kesalahan, (Jakarta: Kencana, 2011), hlm. 70.

${ }^{35}$ Romli Atmasasmita, Perbandingan Hukum Pidana, (Bandung: Mandar Maju, 2000), hlm. 67.

${ }^{36}$ Adami Chazawi dan Ardi Ferdian, Tindak Pidana Informasi \& Transaksi Elektronik Penyerangan Terhadap Kepentingan Hukum Pemanfaatan Teknologi Informasi dan Transaksi Elektronik, (Malang: BayuMedia Publishing, 2011), hlm. 128 
Vol. 3 No. 2 Juli 2021

Menurut Riduan Syahrani yang dimaksud dengan pembuktian adalah penyajian alat-alat bukti yang sah menurut hukum kepada Hakim yang memeriksa suatu perkara guna memberikan kepastian tentang kebenaran peristiwa yang dikemukakan. ${ }^{37}$

Keberadaan alat bukti sangat penting terutama untuk menunjukkan adanya peristiwa hukum yang telah terjadi. Menurut PAF Lamintang, orang dapat mengetahui adanya dua alat bukti yang sah belum cukup bagi hakim untuk menjatuhkan pidana terhadap seseorang. Tetapi dari alat-alat bukti yang sah itu hakim juga perlu memperoleh keyakinan, bahwa suatu tindak pidana benar-benar telah terjadi. Adanya alat bukti yang sah sangat penting bagi hakim pidana dalam meyakinkan dirinya membuat putusan atas suatu perkara. ${ }^{38}$

Dalam ketentuan Pasal 42 UU ITE diatur bahwa penyidikan terhadap tindak pidana UU ITE dilakukan berdasarkan ketentuan Kitab Undang-Undang Hukum Acara Pidana (KUHAP) dan ketentuan dalam UU ITE itu sendiri. Alat bukti yang sah berdasarkan Pasal 184 KUHAP yaitu : 1. Keterangan saksi; 2. Keterangan ahli; 3. Surat; 4. Petunjuk; dan 5. Keterangan terdakwa.

Berkaitan dengan kasus-kasus kejahatan di media sosial atau elektronik, UU ITE mengatur tentang alat bukti selain yang diatur dalam Pasal 184 KUHAP. Pasal 5 ayat (1) UU ITE menegaskan bahwa yang termasuk alat bukti adalah :

1. Informasi elektronik dan/atau dokumen elektronik

2. Hasil cetak informasi elektronik dan/atau dokumen elektronik.

Dalam Pasal 5 ayat (2) UU ITE diatur bahwa Informasi Elektronik dan Dokumen Elektronik dan/atau hasil cetaknya sebagaimana yang dimaksud dalam ayat (1) merupakan perluasan dari alat bukti yang sah sesuai dengan hukum acara yang berlaku di Indonesia. Dari ketentuan Pasal 5 ayat (2) ini diketahui bahwa alat bukti Informasi Elektronik dan Dokumen Elektronik bukanlah alat bukti yang lain dan terpisah dengan alat-alat bukti dalam Pasal 184 KUHAP akan tetapi UU ITE tidak menjelaskan perluasan dari alat bukti yang mana diantara 5 (lima) alat bukti dalam Pasal 184 KUHAP tersebut.

Meskipun demikian, Informasi Elektronik dan Dokumen Elektronik seperti yang didefinisikan oleh Pasal 1 angka 1 dan angka 4 UU ITE, mempunyai sifat yang sama dengan alat bukti surat. Sifat yang sama tersebut terletak pada tulisan dan/atau gambar yang dapat dilihat dan dibaca serta mengandung makna tertentu, maka frasa "merupakan perluasan" dalam kalimat Informasi Elektronik dan/atau Dokumen Elektronik dan/atau hasil cetaknya sebagaimana dimaksud pada Pasal 5 ayat (1) merupakan perluasan dari alat bukti yang sah sesuai dengan Hukum Acara yang berlaku di Indonesia, harus diartikan sebagai perluasan alat bukti surat. ${ }^{39}$

Dalam hubungannya dengan alat bukti petunjuk, maka alat bukti Informasi Elektronik dan Dokumen Elektronik sebagai perluasan alat bukti surat, atau sama kedudukan dan fungsinya sebagai alat bukti surat, maka juga berkedudukan dan berfungsi sama dengan alat bukti surat dalam hal digunakan sebagai bahan untuk membentuk alat bukti petunjuk. Meskipun kedudukan dan fungsi alat bukti Informasi Elektronik dan Dokumen Elektronik sama dengan alat bukti surat namun ada batasbatas keberlakuannya. Dalam Pasal 5 ayat (4) UU ITE ditentukan bahwa mengenai Informasi Elektronik dan/atau Dokumen Elektronik sebagaimana dimaksud pada ayat (1) tidak berlaku untuk: ${ }^{40}$

a. "Surat yang menurut Undang-Undang harus dibuat dalam bentuk tertulis; dan

b. Surat beserta dokumennya yang menurut Undang-Undang harus dibuat dalam bentuk akta notarial atau akta yang dibuat oleh pejabat pembuat akta".

Dalam pembuktian perkara pidana ujaran kebencian yang merupakan alat bukti, yaitu: keterangan saksi, keterangan ahli, surat, petunjuk, keterangan terdakwa, informasi elektronik dan

\footnotetext{
${ }^{37}$ Riduan Syahrani, Buku Materi Dasar Hukum Acara Perdata, (Bandung: Citra Aditya Bakti, 2000),
} hlm. 75 .

\footnotetext{
${ }^{38}$ Ibid., hlm. 42

${ }^{39}$ Adami Chazawi dan Ardi Ferdian, Op.cit., hlm. 226.

${ }^{40}$ Ibid.
} 
Vol. 3 No. 2 Juli 2021

dokumen elektronik dan/atau hasil cetaknya. Namun yang harus tetap diperhatikan dalam pengajuan informasi elektronik dan dokumen elektronik sebagai alat bukti dalam persidangan adalah :

1. Keaslian atau keotentikan alat bukti;

2. Isi atau substansi alat bukti;

3. Kesesuaian antara alat bukti yang satu dengan yang lain.

Berdasarkan uraian-uraian tersebut di atas, maka ketentuan peraturan perundang-undangan yang mengatur pertanggungjawaban pidana terhadap pelaku tindak pidana ujaran kebencian adalah : Pasal 156 KUHP; Pasal 157 KUHP; Pasal 310 KUHP; Pasal 311 KUHP; Pasal 28 ayat (2) jis. Pasal 45A ayat (2) Undang-Undang No. 19 Tahun 2016 tentang Informasi dan Transaksi Elektronik; Pasal 16 Undang-Undang No. 40 Tahun 2008 tentang Penghapusan Diskriminasi Ras dan Etnis.

Dalam menentukan pertanggungjawaban pidana terhadap pelaku tindak pidana ujaran kebencian di media sosial harus mengacu kepada undang-undang yang bersifat khusus. Kenyataannya sampai saat ini, Indonesia belum memiliki Undang-Undang penanganan terhadap tindak pidana ujaran kebencian (Hate Speech) secara khusus. Meskipun tindak pidana ini sudah terakomodir dalam UU ITE, namun mengingat perkembangan zaman dan teknologi yang semakin maju sehingga jenis kejahatan semakin berkembang pemerintah diharapkan dapat menciptakan aturan yang lebih khusus agar tidak terjadi multitafsir dalam penegakan hukumnya.

Berdasarkan asas lex specialis derogat legi generali pertanggungjawaban tindak pidana ujaran kebencian di media sosial mengacu pada ketentuan dalam Pasal 28 ayat (2) jis. Pasal 45A ayat (2) Undang-Undang No. 19 Tahun 2016 tentang Perubahan Atas Undang-Undang No. 11 Tahun 2008 tentang Informasi dan Transaksi Elektronik berupa pidana penjara maksimal 6 tahun dan/atau pidana denda paling banyak Rp. 1.000.000.000,00 (satu miliar rupiah).

Informasi Elektronik dan Dokumen Elektronik dan/atau hasil cetaknya merupakan perluasan dari alat bukti yang sah sesuai dengan hukum acara yang berlaku di Indonesia sebagaimana diatur dalam Pasal 5 UU ITE. Alat bukti Informasi Elektronik dan Dokumen Elektronik dan/atau hasil cetaknya tersebut bukanlah alat bukti yang lain dan terpisah dengan alat-alat bukti dalam Pasal 184 KUHAP melainkan berkedudukan dan berfungsi sama dengan alat bukti surat sekaligus dapat digunakan untuk membentuk alat bukti petunjuk.

KUHAP secara utuh tidak lagi dapat menjadi landasan hukum pembuktian dalam perkara cyber crime di masa sekarang. UU ITE pun masih memiliki keterbatasan dalam hal pembuktian apalagi ditambah jika aparat penegak hukum sendiri tidak memiliki kemampuan dalam bidang teknologi informasi. Sangat penting adanya upaya optimalisasi terhadap peraturan yang mengatur pembuktian terhadap kejahatan teknologi informasi serta kesiapan aparat penegak hukum dalam menghadapi kejahatan di media sosial.

\section{Analisis Yuridis Bukti Digital (Digital Evidence) Dalam Pembuktian Perkara Tindak Pidana} Ujaran Kebencian Pada Putusan Pengadilan Negeri Medan No. 3168/Pid.Sus/2018/PN.Mdn.

Dalam penggunaan bukti digital (digital evidence) atau bukti elektronik (electronic evidence) pada Putusan Pengadilan Negeri Medan No. 3168/Pid.Sus/2018/PN.Mdn., yang telah diputus oleh majelis hakim yang menyidangkannya, maka adapun bukti-bukti tersebut, yaitu:

1. 1 (satu) buah Flashdisk Toshiba 4 GB yang berisikan screenshot facebook Himma Dewiyana dan File akun Facebook Himma Dewiyana.

2. 3 (tiga) screenshot Facebook akun Himma Dewiyana.

Adapun alat yang digunakan, yaitu:

1. 1 (satu) Unit Handphone Iphone 6S warna silver; dan

2. 1 (satu) buah Simcard Mentari Nomor 081533807888.

Adapun konten (informasi elektronik) yang disebarluaskan oleh terdakwa adalah berasal dari akun facebook yang menggunakan profil Pembela Islam, terkait dengan caption, yaitu: "Wow ...TERUNGKAP AKHIR'Y AWAL PEMICU KERUSUHAN D MAKO BRIMOB TERNYATA 
Vol. 3 No. 2 Juli 2021

BKN SOAL MAKANAN,TETAPI KRN KITAB QUR'AN SAKU MILIK SALAH SATU ISTRI PEMBESUK D BUANG SAAT PEMERIKSAAN... "Ini dia pemicunya Sodara, Kitab Al-Quran dibuang"; yang diposting pada tanggal 12 Mei 2018, yang memiliki kaitan dengan postingan Terdakwa tanggal 13 Mei 2018 terkait dengan caption "Skenario pengalihan yg sempurna...\#2019Ganti Presiden";

Menurut majelis hakim dalam pertimbangan putusannya berpendapat bahwasanya caption postingan terdakwa yang memuat data tentang tulisan, gambar, kode yang memiliki arti atau dapat dipahami oleh orang yang mampu memahaminya merupakan "data elektronik". Hal ini sesuai bunyi ketentuan Pasal 1 angka 1 UU ITE bahwasanya "Informasi Elektronik" adalah satu atau sekumpulan "data elektronik"... dst.

Sebagaimana telah diuraikan pada bab sebelumnya bahwasanya "Informasi Elektronik" dan/atau "Dokumen Elektronik" merupakan alat bukti yang sah, maka majelis hakim memberikan pertimbangan berdasarkan perspektif positivistik. Sebab dalam hal ini hakim sebagai corong undangundang. ${ }^{41}$ Menurut Sigid Suseno, "Informasi Elektronik" dan/atau "Dokumen Elektronik" adalah bukti elektronik yang juga merupakan bukti digital.

Dalam teori pembuktian yang dianut di Indonesia adalah sistem pembuktian menurut undang-undang secara negatif. Menurut Andi Hamzah, sistem pembuktian negatif ini, pemidanaan didasarkan kepada pembuktian berganda yaitu pada peraturan perundang-undangan dan keyakinan hakim, dan menurut undang-undang keyakinan hakim tersebut bersumberkan pada peraturan perudnang-undangan. ${ }^{42}$ Dengan demikian jelas bahwa dalam menjatuhkan pidana kepada terdakwa, hakim harus mendasarkannya pada 2 (dua) alat bukti yang sah dan keyakinan hakim yang menyidangkannya. Keyakinan hakim tersebut dibangun berdasarkan minimal 2 (dua) alat bukti yang sah. Tanpa minimal alat bukti dimaksud, maka keyakinan hakim tidak akan terbangun.

Dikaitkan dengan Putusan Pengadilan Negeri Medan No. 3168/Pid.Sus/2018/PN.Mdn., maka hakim menggunakan alat bukti elektronik sebagai salah satu alat bukti yang sah menurut UU ITE untuk menyatakan terdakwa bersalah dan selanjutnya menjatuhkan hukuman. Namun, menurut Ahli Ade Charge, Mahmud Mulyadi dalam membuktikan kasus tindak pidana ujaran kebencian, maka harus dibuktikan terlebih dahulu subjek, objek, dan tujuan serta akibat dari postingan terdakwa tersebut. Dalam hal ini, postingan terdakwa ditujukan kepada siapa subjeknya, lalu apa objek yang dituju dari postingan tersebut, serta tujuannya harus memenuhi unsur "Menimbulkan Rasa Kebencian atau Permusuhan Individu dan/atau Kelompok Masyarakat Tertentu Berdasarkan Suku, Agama, Ras, dan Antar-golongan (SARA)".

Dalam hal ini, kebencian yang ditimbulkan kepada pemerintah yang menurut terdakwa sudah menyulitkan terdakwa untuk hidup dan berkehidupan karena bahan pokok mahal harganya. Lalu, objeknya kelompok masyarakat tertentu berdasarkan SARA, dalam hal ini adalah ummat Islam yang diprovokasi oleh terdakwa bahwasanya peristiwa ledakan bom di Surabaya dan ganti presiden 2019 merupakan pengalihan issue dari fakta kejadian yang sebenarnya, yaitu bahan pokok mahal harganya.

Majelis hakim yang mendasarkan kepada "Data Elektronik" sebagai bukti yang sah ditambah dengan keterangan saksi-saksi dan Ahli Bahasa dari Balai Bahasa Provinsi Sumatera Utara, yang menyatakan bahwasanya postingan terdakwa menimbulkan keresahan di masyarakat dan dapat menimbulkan provokasi antar umat beragama, ditambah dengan keterangan Mahmud Mulyadi, maka majelis hakim menyatakan seluruh unsur-unsur pasal yang didakwakan kepada terdakwa telah terpenuhi. Oleh sebab itu, terdakwa dijatuhi hukuman 1 (satu) tahun pidana penjara dengan masa percobaan 2 (dua) tahun serta denda sebesar Rp. 10 juta.

${ }^{41}$ Hakim sebagai corong undang-undang, maksudnya bahwa hakim berfungsi menerapkan undangundang, bukan berfungsi menemukan hukum atau nilai-nilai yang hidup dalam masyarakat.

${ }^{42}$ Andi Hamzah dalam Hari Sasangka dan Lily Rosita, Op.cit., hlm. 16. 
Vol. 3 No. 2 Juli 2021

Sesungguhnya, dalam menerapkan ketentuan Pasal 28 ayat (2) Jo. Pasal 45A ayat (2) UU ITE, benar apa yang disampaikan oleh Mahmud Mulyadi bahwasanya harus ada akibat atau efek yang ditimbulkan dari postingan terdakwa. Dalam hal ini, postingan terdakwa tersebut tidak menimbulkan dampak bagi masyarakat luas, sehingga terdakwa tidak layak untuk dijatuhi hukuman. Memang, postingan tersebut "berpotensi" menimbulkan keributan dalam pranata bermasyarakat, akan tetapi keribuatan dalam masyarakat sebagai akibat dari postingan tersebut belum terjadi, sehingga terdakwa tidak patut dan layak menurut hukum untuk dijatuhi hukuman.

\section{KESIMPULAN}

Adapun benang merah yang dapat dijadikan kesimpulan dalam penelitian ini, antara lain :

1. Penggunaan bukti digital (digital evidence) dalam perkara tindak pidana ujaran kebencian di media sosial didasarkan kepada undang-undang yang bersifat khusus (lex specialist) yaitu: Pasal 28 ayat (2) Jo Pasal 45A ayat (2) Undang-Undang No. 19 Tahun 2016 tentang Perubahan Atas Undang-Undang No. 11 Tahun 2008 tentang Informasi dan Transaksi Elektronik. Dalam penggunaan bukti digital merupakan salah satu syarat untuk pemenuhan unsur pasal tersebut.

2. Bukti digital (digital evidence) dalam pembuktian perkara tindak pidana ujaran kebencian pada Putusan Pengadilan Negeri Medan No. 3168/Pid.Sus/2018/PN.Mdn., adalah berupa screenshot dari akun facebook milik terdakwa sebagai konten yang berisi informasi. Penggunaan screenshot facebook tersebut tidak dapat dilepaskan dari fakta-fakta yang terungkap di depan persidangan (delik materiil) yaitu harus timbul suatu kebencian berupa reaksi dan sebagainya. Postingan terdakwa tidak memenuhi unsur menghina lembaga ataupun kepada individu karena objek kepada siapa ujaran kebencian tersebut disampaikan harus jelas. Dalam contoh kasus yang diangkat dalam penelitian ini, objeknya tidak jelas ditujukan kepada siapa kebencian tersebut. Sehingga unsur ujaran kebencian tidak terpenuhi.

\section{SARAN}

Adapun rekomendasi yang dapat dijadikan saran dalam penelitian ini, antara lain :

1. Penggunaan bukti digital atau bukti elektronik yang digunakan sebagai alat bukti yang sah dalam pranata hukum acara pidana untuk pembuktian di depan pengadilan harus membuat terang dan jelas tindak pidana ujaran kebencian yang terjadi. Bukti digital atau bukti elektronik tersebut juga harus memenuhi syarat-syarat keabsahannya, seperti: dapat diakses, ditampilkan, dijamin keutuhannya, dan dapat ditpertanggungjawabkan. Penggunaan bukti elektronik untuk membantu tercapainya tujuan hukum acara pidana yaitu kebenaran materiil (keadilan substansial).

2. Sebaiknya majelis hakim dengan asas peradilan tidak boleh menolak untuk memeriksa dan memutus perkara serta hakim wajib menggali nilai-nilai hukum yang tumbuh dan berkembang dalam masyarakat, maka dalam perkara tindak pidana ujaran kebencian harus membuktikan kepada siapa ujaran kebencian tersebut ditujukan (sebagai objek tindak pidana) sehingga dapat memenuhi unsur ujaran kebencian sebagaimana dimaksud dalam ketentuan Pasal 28 ayat (2) Jo Pasal 45A ayat (2) Undang-Undang No. 19 Tahun 2016 tentang Perubahan Atas Undang-Undang No. 11 Tahun 2008 tentang Informasi dan Transaksi Elektronik.

\section{DAFTAR PUSTAKA \\ Buku}

Ali, Achmad., Keterpurukan Hukum di Indonesia, Jakarta : Ghalia Indonesia, 2002.

Amirudin dan Zainal Asikin, Pengantar Metode Penelitian Hukum, Jakarta : Rajawali Press, 2010. 
Vol. 3 No. 2 Juli 2021

Atmasasmita, Romli., Perbandingan Hukum Pidana, Bandung: Mandar Maju, 2000.

Bahri, Idik Saeful., Cyber Crime Dalam Sorotan Hukum Pidana, Yogyakarta: Bahasa Rakyat, 2020.

Black, Henry Campbell., Bryan A. Garner (Editor), Black's Law Dictionary, Ed. ke-8, Minnesota : West Group, 2004.

Bungin, Burhan., Penelitian Kualitatif : Komunikasi, Ekonomi, Kebijakan Publik, dan Ilmu Sosial Lainnya, Jakarta : Kencana, 2009.

Chazawi, Adami., dan Ardi Ferdian, Tindak Pidana Informasi \& Transaksi Elektronik Penyerangan Terhadap Kepentingan Hukum Pemanfaatan Teknologi Informasi dan Transaksi Elektronik, Malang: BayuMedia Publishing, 2011.

Friedman, Lawrence M., American Law An Introduction (Hukum Amerika Sebuah Pengantar), diterjemahkan Wishnu Basuki, Cet. Ke-1, Jakarta : Tatanusa, 2001.

Fuady, Munir., Teori Hukum Pembuktian Pidana dan Perdata, Bandung : Citra Aditya Bakti, 2012.

Hamzah, Andi., Hukum Acara Pidana Indonesia, Edisi Revisi, Jakarta : Sinar Grafika, 2001.

Harahap, M. Yahya., Pembahasan Permasalahan dan Penerapan KUHAP (Pemeriksaan Sidang Pengadilan, Banding, Kasasi dan Peninjauan Kembali), Jakarta : Sinar Grafika, 2000. Pembuktian dan Putusan Pengadilan, Jakarta: Sinar Grafika, 2016.

Huda, Chairul., Dari Tiada Pidana Tanpa Kesalahan Menuju Kepada Tiada Pertanggungjawaban Pidana Tanpa Kesalahan, Jakarta: Kencana, 2011.

Ibrahim, Jhonny., Teori dan Metodologi Penelitian Hukum Normatif, Surabaya: Bayumedia, 2006.

Kelsen, Hans., Teori Hukum Murni : Dasar-Dasar Ilmu Hukum Normative, diterjemahkan oleh Raisul Muttaqien, disunting oleh Nurainun Mangunsong, Cet. ke-3, Bandung : Nusa Media, 2010.

Lamintang, P.A.F., Dasar-Dasar Hukum Pidana Indonesia, Bandung: Citra Aditya Bakti, 1997.

Manan, Abdul., Penerapan Hukum Acara Perdata di Lingkungan Peradilan Agama, Jakarta : Kencana, 2008.

Mertokusumo, Sudikno., Mengenal Hukum Suatu Pengantar, Yogyakarta: Liberty, 2002.

Mertokusumo, Sudikno., dan A. Pitlo, Bab-Bab Tentang Penemuan Hukum, Bandung: Citra Aditya Bakti, 2013.

Mulyadi, Lilik., Bunga Rampai Hukum Pidana: Perspektif Teoretis dan Praktik, Bandung: Alumni, 2008. Bandung: Alumni, 2012.

Panjaitan, Daniel., Panduan Bantuan Hukum Di Indonesia Pedoman Anda Memahami dan Menyelesaikan Masalah Hukum, Jakarta: YLBHI dan PSHK, 2006.

Rifai, Ahmad., Penemuan Hukum oleh Hakim Dalam Perspektif Hukum Progresif, Jakarta: Sinar Grafika, 2010.

Sasangka, Hari., dan Lily Rosita, Hukum Pembuktian Dalam Perkara Pidana, Bandung: Mandar Maju, 2003.

Shidarta, Tafsir Hukum Hakim Sarpin, http://business-law.binus.ac.id/2015/02/19/tafsir-hukumhakim-sarpin/, diakses Selasa, 07 Juli 2020.

Simorangkir, J.C.T., dkk., Kamus Hukum, Jakarta : Aksara Baru, 1985.

Sitompul, Josua., Cyberspace, Cybercrimes, Cyberlaw: Tinjauan Aspek Hukum Pidana, Jakarta: Tatanusa, 2012.

Soekanto, Soerjono., Sosiologi Suatu Pengantar, Cet. Ke-42. Jakarta : Rajawali Press, 2009.

Sofyan, Andi., dan Abd. Asis, Hukum Acara Pidana: Suatu Pengantar, Jakarta : Kencana Prenadamedia Group, 2014.

Sofyan, Andi., dan Nur Azisa, Buku Ajar: Hukum Pidana, Cet. Ke-1, Makassar: Pustaka Pena Press, 2016. 
Fakultas Hukum Universitas Komputer Indonesia

Vol. 3 No. 2 Juli 2021

Suhariyanto, Budi., Tindak Pidana Teknologi Informasi (Cybercrime), Jakarta: Raja Grafindo Persada, 2014

Syahrani, Riduan., Buku Materi Dasar Hukum Acara Perdata, Bandung: Citra Aditya Bakti, 2000.

\section{Karya Ilmiah}

Arifin, Rita Wahyuni., "Peran Facebook Sebagai Media Promosi Dalam Mengembangkan Industri Kreatif", Bina Insani ICT Journal Vol. 2 No. 2, (2015).

DW., Miller, dan Miller CG, "On Evidence, Medical and Legal", Journal of American Physicians and Surgeons, Vol. 10, No. 3, 2005.

Fakhriah, Efa Laela., "Kedudukan Bukti Elektronik sebagai Alat Bukti Di Pengadilan Setelah Berlakunya Undang-Undang No 11 Tahun 2008 tentang Informasi dan Transaksi Elektronik", Makalah disampaikan pada Seminar Terbatas kerjasama Badan Litbang Diklat Kumdil Mahkamah Agung RI dengan Perguruan Tinggi dengan Thema: "Validitas Alat Bukti Transaksi Elektronik Perbankan Sebagai Alat Bukti Di Pengadilan Setelah Berlakunya UU No. 11 Tahun 2008", tanggal 25 November 2009, Grand Pasundan Hotel, Bandung.

Hadisuprapto, Paulus., "Ilmu Hukum (Pendekatan Kajiannya)", Makalah disajikan dalam Acara Kuliah Umum (Stadium Generale) pada Program Magister Ilmu Hukum, Universitas Jambi, tanggal 23 Mei 2009.

Makarim, Edmon., "Keautentikan Dokumen Publik Elektronik Dalam Administrasi Pemerintahan dan Pemerintahan Publik", Jurnal Hukum dan Pembangunan No. 4, (2015).

Mangantibe, Veisy. "Ujaran Kebencian dalam Surat Edaran Kapolri No. SE/6/X/2015 Tentang Penanganan Ucapan Kebencian (Hate Speech)." Lex Crimen, Vol. 5, No. 1, 2016.

Marzuni, Elfi., "Manajemen Persidangan Perkara Pidana di Pengadilan Negeri", Makalah disampaikan dalam Workshop dan Orientasi Hukum Angkatan I dan II Kementerian Agama Kanwil Provinsi Daerah Istimewa Yogyakarta, hari Selasa tanggal 12 Juli 2011.

Nugroho, Dedy Muchti., "Eksistensi Alat Bukti Elektronik Dalam Sistem Hukum Pembuktian di Indonesia dari Perspektif Hakim", Jurnal Ilmu Hukum QISTIE, Vol. 8, No. 1, (2015).

Permatasari, Gusti Ayu Made Gita., "Tinjauan Yuridis Mengenai Pengaturan dan Pertanggungjawaban Pidana Terhadap Tindak Pidana Ujaran Kebencian di Media Sosial", Journal Ilmu Hukum Vol. 07 No. 03, (2018).

Pusat Litbang Kejaksaan Agung RI, "Studi Tentang Peranan Alat Bukti Keterangan Ahli Dalam Penanganan Perkara Tindak Pidana Korupsi”, Litbang Kejagung RI, Jakarta, 2008.

Ramiyanto, "Bukti Elektronik Sebagai Alat Bukti Yang Sah Dalam Hukum Acara Pidana", Jurnal Hukum dan Peradilan Vol. 6 No. 2, (2017).

Sampurna, Budi., "Bukti Medis Versus Bukti Hukum", Indonesian Journal of Legal and Forensic Sciences, Vol. 2, No. 2, (2012).

Santhos Wachjoe Prijambodo, "Alat Bukti Ilmiah", Makalah Mahasiswa Program Doktoral pada Program Doktoral Ilmu Hukum (PDIH) Fakultas Hukum Universitas Islam Sultan Agung, Semarang, 12 April 2016.

Tambaani, Gerry., "Keabsahan Alat Bukti Elektronik Ditinjau dari Pasal 184 Kitab Undang-Undang Hukum Acara Pidana", Jurnal Lex Crimen Vol. VII No. 4, (2018).

Wahyudi, Johan., "Dokumen Elektronik Sebagai Alat Bukti Pada Pembuktian di Pengadilan", Perspektif Vol. XVII No. 2, (2012).

Wargakusumah, Hasan., "Penguasaan Tanah Dalam Hukum Tanah dan Penerapannya di Kawasan Industri”, Disertasi, Program Doktor Ilmu Hkum Universitas Gadjah Mada, Yogyakarta, 2001.

Wijayanti, Alcadini., "Perkembangan Alat Bukti Dalam Pembuktian Tindak Pidana Berdasarkan Undang-Undang Khusus dan Implikasi Yuridis Terhadap KUHAP", Diponegoro Law Review Vol. 1 No. 4, (2012). 
Vol. 3 No. 2 Juli 2021

Wuryantoro, Aris., "Peranan Penerjemahan Istilah dalam Bahasa Indonesia", Makalah disampaikan dalam Prosiding Seminar Nasional PESAT 2005 di Auditorium Universitas Gunadarma, Jakarta, 23-24 Agustus 2005.

Yusmita, Mei., dkk., "Pemanfaatan Whatsapp Messenger Sebagai Media Komunikasi Antar Pribadi Mahasiswa Ilmu Komunikasi”, Jurnal Ilmu Komunikasi UHO: Jurnal Penelitian Kajian Ilmu Komunikasi dan Informasi Vol. 3 No. 4, (2018).

\section{Media Massa \& Internet}

Berita Online Pewarta Indonesia, "Ningsih : MRI Sebagai Alat Bukti Hukum Yang Ilmiah, Inovatif, Kredibel, dan Mutakhir", http://www.pewarta-indonesia.com/berita/hukum/7284-mrisebagai-alat-bukti-hukum-yang-ilmiah-inovatif-kredibel-dan-mutakhir.pdf., diterbitkan pada Selasa, tanggal 20 Desember 2011.

Harian Kompas, "Investigasi Ilmiah Menjadi Petunjuk Ungkap Kasus Mirna”, diterbitkan pada hari Senin, tanggal 01 Februari 2016.

Harian Surat Kabar New York Times, "India's Use of Brain Scan in Courts Dismays Critics", diterbitkan pada Senin, tanggal 15 September 2008.

Sitompul, Josua., "Syarat dan Kekuatan Alat Bukti Elektronik", http://m.hukumonline.com/klinik/detail/cI5461/syarat-dan-kekuatan-hukum-alat-buktielektronik., diakses Senin, 06 Juli 2020.

Website Resmi Ensiklopedia Bebas Wikipedia.com, “Television Sirkuit Tertutup", http://id.wikipedia.org/wiki/Television-Sirkuit-Tertutup., diakses Senin, 06 Juli 2020.

Website Resmi Hukumonline.com, "Penanganan Kasus Pidana Lingkungan Masih Cara Konvensional, Tidak Mudah Menyeret Pelaku Pencemaran Lingkungan", http://www.hukumonline.com/berita/baca/lt52e7bfcf44fef/penanganan-kasus-pidanalingkungan-masih-cara-konvensional., diakses Sabtu, tanggal 26 Oktober 2019.

\section{Peraturan Perundang-Undangan}

Herzien Inlandsch Reglement (H.I.R) atau Reglemen Indonesia Yang Diperbaharui (Staatsblad 1984 : No. 16 yang diperbaharui dengan Staatsblad 1941 No. 44) berlaku untuk Jawa dan Madura.

Kitab Undang-Undang Hukum Pidana (KUHP).

Undang-Undang No. 8 Tahun 1981 tentang Hukum Acara Pidana (KUHAP).

Undang-Undang No. 8 Tahun 1997 tentang Dokumen Perusahaan.

Undang-Undang No. 2 Tahun 2002 tentang Kepolisian Negara Republik Indonesia.

Undang-Undang No. 16 Tahun 2004 tentang Kejaksaan RI.

Undang-Undang No. 11 Tahun 2008 tentang Informasi dan Teknologi Elektronik sebagaimana telah diubah dengan Undang-Undang No. 19 Tahun 2016 tentang Perubahan Atas UndangUndang No. 11 Tahun 2008 tentang Informasi dan Transaksi Elektronik.

Peraturan Kapolri No. 10 Tahun 2010 tentang Tata Cara Pengelolaan Barang Bukti di Lingkungan Kepolisian Negara Republik Indonesia.

Peraturan Kapolri No. 14 Tahun 2012 tentang Manajemen Penyidikan Tindak Pidana.

Peraturan Kabareskrim No. 3 Tahun 2014 tentang Standard Operasional Prosedur Pelaksanaan Penyidikan Tindak Pidana.

Surat Edaran Kapolri No. SE/6/X/2015 tentang Penanganan Ujaran Kebencian (Hate Speech).

Putusan Pengadilan

Putusan Pengadilan Negeri Medan No. 3168/Pid.Sus/2018/PN.Mdn., tertanggal 23 Mei 2019.

Putusan Mahkamah Konstitusi RI No. 20/PUU-XVI/2016 tentang Pengujian Undang-Undang No. 11 Tahun 2008 tentang Informasi dan Transaksi Elektronik dan Undang-Undang No. 20 Tahun 2001 tentang Perubahan Atas Undang-Undang No. 31 Tahun 1999 tentang Pemberantasan Tindak Pidana Korupsi terhadap Undang-Undang Dasar Negara Republik Indonesia Tahun 1945. 